\title{
Using Goal-Programming to Model the Effect of Stakeholder Determined Policy and Industry Changes on the Future Management of and Ecosystem Services Provision by Ireland's Western Peatland Forests
}

\author{
Edwin Corrigan ${ }^{*}{ }^{\dagger}$ and Maarten Nieuwenhuis ${ }^{\dagger}$ \\ UCD Forestry, School of Agriculture \& Food Science, UCD, Belfield, Dublin 4, Ireland; \\ maarten.nieuwenhuis@ucd.ie \\ * Correspondence: edwintcorrigan@gmail.com; Tel.: +353-87-7552-666 \\ † These authors contributed equally to this work. \\ Academic Editor: Jose G. Borges \\ Received: 12 July 2016; Accepted: 17 December 2016; Published: 23 December 2016
}

\begin{abstract}
Recent studies have highlighted land-use conflicts between stakeholder groups in Ireland. Some of these conflicts can be attributed to European directives, designed with sustainable forest management principles in mind, but imposing incoherencies for land-owners and stakeholders at the local level. This study, using Ireland's Western Peatland forests as a case study area, focused on the development and implementation of a goal programming model capable of analysing the long term impact of policy and industry changes at the landscape level. The model captures the essential aspects of the changes identified by local level stakeholders as influencing forest management in Ireland and determines the future impact of these changes on ecosystem services provisions. Initially, a business as usual potential future is generated. This is used as a baseline against which to compare the impact of industry and policy changes. The model output indicated that the current forest composition is only really suited to satisfy a single, financial objective for forest management. The goal programming model analysed multiple objectives simultaneously and the results indicated that the stakeholders' desired ecosystem service provisions in the future will be more closely met by diversifying the forest estate and/or by changing to an alternative, non-forest land-use on less productive areas.
\end{abstract}

Keywords: Remsoft; optimisation; land-use change; forest management; scenario analysis; sustainable forest management

\section{Introduction}

Proper implementation of Sustainable Forest Management (SFM) will depend on an acceptable balance between the three pillars of SFM, i.e., the economic, ecological and the social, as quantified by their indicators [1-3]. Each pillar provides functional support to individuals at the local, national and global scale [4]. It has been suggested that Ecosystem Services (ESs), a utilitarian concept, may prove useful to identify this balance [5]. A full history of the evolution of the ES concept is described by Gómez-Baggethun et al. [6]. Briefly, the origin of the concept dates back to the late 1960s [7]. It was used in the 1970s to capture public interest in terms of biodiversity conservation [8]. Since then, the number of academic publications referring to the term ESs has gradually increased prompting the Millennium Ecosystem Assessment; a major piece of work which provided an indication of the level of degradation of the world's ESs [9]. The concept of ESs makes it possible to evaluate the trade-offs and the compatibilities between different management scenarios. However, debate continues about the most appropriate method to define and quantify ESs with consistency. De Groot et al. [10] have suggested indicators that link ESs to human well-being. In Ireland, political attention has focused on 
specific ESs, and land-use disputes have identified ESs that are strongly related to human welfare. A certain amount of research into these ESs has been carried out [11-14] and most of the ESs analysed can be categorised as outlined by De Groot, Alkemade, Braat, Hein and Willemen [10]: food, raw materials, climate regulation, gene pool protection, water regulation, and recreation.

Since the 1960s, many forests in Ireland have been established with a focus on generating revenue and this remains their main objective. This single financially oriented objective has guided early forest Decision Support System (DSS) research in Ireland in the past. Nieuwenhuis and Williamson [15] developed a system for timber harvesting and sawmill delivery while minimising costs. More recently, SFM has come to the fore in Irish forest management and research effort has shifted, becoming less focused on timber production only and more on the integration of non-timber benefits with a sustainable timber supply, using the ecosystem services concept. The potential to group sub-compartments (the smallest unit of management used by Coillte, the Irish State forestry board) to create economically viable blocks for harvesting was explored by Nieuwenhuis and Tiernan [2] using Mixed Integer Programming. They went on to implement some SFM constraints and compared their economic impact.

However, the concept of SFM requires the optimisation of multiple objectives. The objective of this paper is to describe the development of a multi-criteria Goal Programming (GP) model capable of investigating the long term impact of policy and industry changes on ES provision levels. The industry and policy changes have been determined by a social science team that worked in parallel as part of a larger project known as INTEGRAL [16]. The INTEGRAL project aimed to bridge the gap between European level policy decision makers and the stakeholders within 20 local regions of EU member states. This study will describe the GP decision support system developed and used on one of these regions in Ireland. The GP method is often used in multi-criteria decision making in forest management planning $[17,18]$, with one of the main reasons being that goal constraints (i.e., soft constraints) allow for a model to produce a feasible solution even if the specified constraint is not met. This means that optimal compromises can be achieved between multiple objectives that are not simultaneously achievable.

\section{Materials and Methods}

The Western Peatland (WP) Case Study Area (CSA) is located in the northwest of Ireland (Figure 1 and Table 1). It is based on one of eight Business Area Units, the method of land division and management used by Coillte. Business Area Unit boundaries follow town land boundaries (as much as possible) and each Business Area Unit was designed to be an independently profitable unit [19]. The location of the WP CSA means that wind exposure is a dominant factor for all land-use options. This study is focused on forestry and hence, the CSA includes only the area that is forest at the beginning of the planning horizon (the planning horizon is the entire number of years that the optimisation algorithm is ran for). Nationally, $44 \%$ of state forests are located on peatlands [20] which indicates that peatland forestry is important even at the national level. Approximately $62 \%$ of the forests in the CSA have a peatland soil type which is more than the national level and will allow for an analysis of various forest management approaches on Ireland's peatlands.

Table 1. Statistics associated with the Western Peatland case study area.

\begin{tabular}{cc}
\hline Descriptor & Western Peatlands \\
\hline Area (approx. ha) & $1,060,000$ \\
Forested area (approx. ha) & 116,000 \\
Average temperature $\left({ }^{\circ} \mathrm{C}\right)$ & $11-12$ \\
Typical annual rainfall $(\mathrm{mm})$ & West: 2000 \\
\hline
\end{tabular}


Table 1. Cont.

\begin{tabular}{|c|c|}
\hline Descriptor & Western Peatlands \\
\hline \multicolumn{2}{|c|}{ Forested land only (as of 2012) } \\
\hline \multicolumn{2}{|c|}{ Forest ownership } \\
\hline Coillte & $64 \%$ \\
\hline Private & $36 \%$ \\
\hline \multicolumn{2}{|c|}{ Yield potential } \\
\hline Economically viable forest * & $82 \%$ \\
\hline Not economically viable forest & $18 \%$ \\
\hline \multicolumn{2}{|c|}{ Age class distribution } \\
\hline $0-10$ years & $15 \%$ \\
\hline $11-20$ years & $34 \%$ \\
\hline $21-30$ years & $27 \%$ \\
\hline $31-40$ years & $15 \%$ \\
\hline $41-50$ years & $6 \%$ \\
\hline 51 years or over & $3 \%$ \\
\hline \multicolumn{2}{|l|}{ Soil type } \\
\hline Brown earths and brown podzolics & $5 \%$ \\
\hline Lithosols & $12 \%$ \\
\hline Gleys/peaty gleys and gleyed grey brown podzolics & $17 \%$ \\
\hline Flushed blanket peat & $48 \%$ \\
\hline Cutaway raised bogs & $18 \%$ \\
\hline \multicolumn{2}{|l|}{ Elevation } \\
\hline Less than $200 \mathrm{~m}$ & $93 \%$ \\
\hline \multicolumn{2}{|c|}{ Distance to watercourse } \\
\hline Less than $200 \mathrm{~m}$ & $56 \%$ \\
\hline Between 200 and $400 \mathrm{~m}$ & $26 \%$ \\
\hline $400 \mathrm{~m}$ or greater & $19 \%$ \\
\hline
\end{tabular}

* Forestry that has a Sitka spruce yield class equivalence of 14 or higher is considered to be economically viable [21].

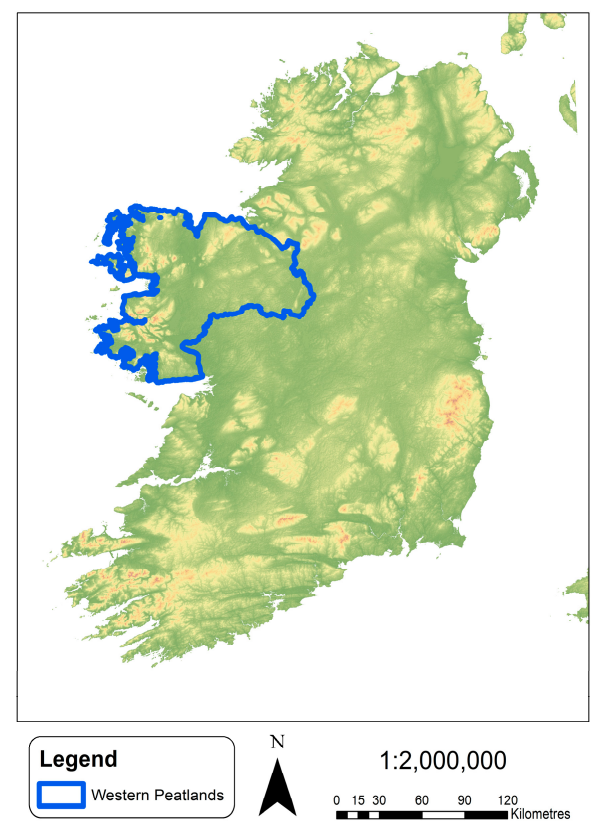

Figure 1. Location and boundaries of the Western Peatland case study area.

\subsection{Introduction to the Western Peatland's Ecosystem Services}

The landscape's climate and soils enforce limitations for tree species selection. A large proportion of the forest area comprises exotic conifers that have a relatively low level of production on the poor 
peat soils compared with the levels on more fertile soils located in other areas of Ireland. The timber produced within parts of this area does have viable potential end uses but also sequesters carbon and it is unclear how these forests should be managed.

The WPs is a popular tourism destination. Water based activities such as fishing and leisure cruising are predominant tourism attractions in the area. The mountainous environment and the reasonably undisturbed landscape (when compared to the typical Irish landscape of commercial agriculture) provide also a canvas for many other recreational activities. Excellent water quality for salmonid fish stocks is essential for tourism, and forest management planning also needs to address concerns about the impacts of forest operations on the viability of populations of the threatened freshwater pearl mussel (Margaritifera margaritifera), a species native to Ireland.

There is concern amongst some about the dominant proportion of the forested landscape that consists of these exotic conifers, and the issues regarding whether or not these forests should be harvested, and if so, should the land be reforested and with which species, or should the area be turned back to its probable previous native land-use. Landscape restoration and biodiversity enhancement are thought by some to also have a positive effect on tourism in the area.

\subsection{Management Approaches}

The management interventions have been categorised into seven, mutually exclusive, forest management approaches (Table 2), i.e., Traditional forest management, Continuous Cover Forestry (CCF), Native Woodland Site (NWS), Non-reforested, Buffer zone (areas within certain proximity of road, watercourse or Freshwater Pearl Mussel (FPM) watercourse) and Bog restoration. The characteristics of the forest site determine which approaches are appropriate for implementation. In Remsoft Woodstock, the smallest management unit used is the development type. Each development type is assigned a management approach based on its characteristics and age. An "existing development type" (i.e., a development type that exists before the optimisation matrix is built) is created from polygons in the GIS layer for each unique combination of:

- Species or land-use

- Productivity

- Proportion of a species in a stand

- Environmental zone

- Soil type

- Site preparation type at establishment

- Owner type

- Elevation

- Water risk factor

- Age

The model described in this study is in a linear programming model II formulation [22]. If an existing development type has the appropriate age and attributes, it is eligible for actions which transition a development type (and all of its associated area) into a future development type. For example, if a development type is eligible for a clearfell action, the existing development type and its entire area would transition into a clearfelled future development type. Further actions and transitions can be carried out for a future development type throughout the planning horizon as long as the development type attributes and age make it eligible for such actions to take place. For example, the clearfelled development type might have the option to be reforested, thinned and clearfelled again within the planning horizon and each of these actions will transition the development type. Accordingly, the Western Peatland forestland was classified into 24,300 development type. Transitions over the planning horizon led to a total of 123,800 future development types. 
Table 2. Forest management approaches.

\begin{tabular}{ll}
\hline \multicolumn{1}{c}{ Management Approach } & \multicolumn{1}{c}{ Description } \\
\hline Traditional forest management & $\begin{array}{l}\text { Forests that are managed under a typical Irish rotation based system, i.e., } \\
\text { commercial thinning, clearfelling and artificial restocking. }\end{array}$ \\
\hline Continuous Cover Forestry (CCF) & $\begin{array}{l}\text { Forest that has a continuous cover. It is thinned at 5-year intervals and can consist of } \\
\text { conifers, broadleaves or a mix. It is assumed that stands regenerate naturally. }\end{array}$ \\
\hline Native Woodland Site (NWS) & $\begin{array}{l}\text { Unique species options at afforestation/reforestation, only available for suitable soil } \\
\text { types. Harvesting options are the same as for CCF management. }\end{array}$ \\
\hline Non-reforested & Cleared land that has not been reforested after 2 years. \\
\hline Buffer zone & $\begin{array}{l}\text { Areas within certain proximity of a road or watercourse that have undergone a } \\
\text { buffer conversion process. There are three types of buffer zone. Within } 20 \mathrm{~m} \text { of a } \\
\text { road: } 10 \mathrm{~m} \text { scrubland, } 10 \mathrm{~m} \text { broadleaves; within } 10 \mathrm{~m} \text { of watercourse or FPM } \\
\text { watercourse: } 10 \mathrm{~m} \text { scrubland; within } 25 \mathrm{~m} \text { of a watercourse within a } 6 \mathrm{~km} \\
\text { hydrological distance of a live FPM site: } 20 \% \text { native broadleaves and } 80 \% \text { scrubland. }\end{array}$ \\
\hline Bog restoration & $\begin{array}{l}\text { Area that undergoes a conversion process to bog. This is only permitted on areas } \\
\text { with a blanket peat soil type. }\end{array}$ \\
\hline
\end{tabular}

\subsection{Current Forest Policy and Business As Usual Scenario}

Directives outlined by the European Union and enforced nationally by Ireland have designated zones for the purpose of maintaining rare habitats. In these areas, forest operations have been restricted. A list of current forest policies and permissible actions within associated zones were established through a review of literature [21,23-25]. This list was verified and refined by a member of the Forest Service Inspectorate. It was translated into CSA forest management planning rules (Table 3). In addition, the following policies were incorporated in the Business As Usual (BAU) scenario:

(1) All Coillte broadleaf forest must be managed under low impact silvicultural systems (i.e., CCF), as per the company policy decision made in 2005.

(2) A stand must be reforested within 2 years of clearfelling (with certain exceptions, e.g., buffer zones and bog restoration).

(3) Clearfell not permitted of stands still in receipt of forest premiums (i.e., before the age of 20 years on afforested land). Farmers who afforested receive grants that cover the cost of establishment and (as per 2012 regulations) receive premiums annually for the first 20 years of their forest's rotation.

Table 3. Permissible forest operations given current forest policy zones in Ireland.

\begin{tabular}{|c|c|c|c|c|}
\hline Relevant Group & $\begin{array}{l}\text { Harvesting } \\
\text { Options }\end{array}$ & Reforestation & $\begin{array}{l}\text { Fertilisation at } \\
\text { Establishment }\end{array}$ & Tending/Thinning \\
\hline Special protection areas & Yes & Yes & Yes & Yes \\
\hline $\begin{array}{l}\text { Special areas } \\
\text { of conservation }\end{array}$ & Yes & $\begin{array}{l}\text { Native woodland } \\
\text { site only }\end{array}$ & Yes & Yes \\
\hline $\begin{array}{l}\text { proposed National } \\
\text { Heritage Area }\end{array}$ & Yes & $\begin{array}{l}\text { Native woodland } \\
\text { site only }\end{array}$ & Yes & Yes \\
\hline National Heritage Area & Yes & $\begin{array}{l}\text { Native woodland } \\
\text { site only }\end{array}$ & Yes & Yes \\
\hline Old Woodland Site & No & $\begin{array}{l}\text { Soil type specific } \\
\text { species choice }\end{array}$ & Yes & No \\
\hline Native Woodland Site & CCF only & $\mathrm{N} / \mathrm{A}$ & No & CCF only \\
\hline Freshwater Pearl Mussel & No CCF & Yes & Yes & Yes \\
\hline $\begin{array}{c}6 \text { KM Freshwater Pearl } \\
\text { Mussel zone }\end{array}$ & No CCF & $\begin{array}{c}20 \text { m setback, } \\
5 \text { m broadleaf buffer }\end{array}$ & No & Yes \\
\hline Road buffer & Yes & $\begin{array}{l}10 \mathrm{~m} \text { setback then } \\
10 \mathrm{~m} \text { broadleaf species }\end{array}$ & Yes & Yes \\
\hline $\begin{array}{l}\text { Non-Freshwater Pearl } \\
\text { Mussel buffer zone }\end{array}$ & No CCF & $10 \mathrm{~m}$ buffer width & No & Yes \\
\hline
\end{tabular}

N/A: No clearfelling takes place and therefore reforestation is not an option for these sites. 


\subsection{GP Mathematical Notation}

The GP model used in this study considers the biophysical LP model results described by Corrigan and Nieuwenhuis [26]. Specifically, the objective function value of the maximisation scenario for each ES is used to set that ES goal value (Table 4). Even though Net Present Value (NPV) is not an ES, it is included in this paper in the list of ESs as it is an important factor of the decision making process. In the case of the water sedimentation risk ES, the goal value was rather set as equal to the objective function value of the minimisation scenario (Table 4). Goals are specified as constraints for each Owner Type (OT; i.e., a mutually exclusive landowner type: Coillte, private forest owners, agricultural ruminant production or tillage landowners) (Equation (1) or (2)), and the deviation variables $n_{q k}$ and $p_{q k}$ are used in the objective function (Equation (3)).

$$
\begin{aligned}
& \sum_{d=1}^{D} \sum_{i=0}^{H-1} \sum_{j=\min \left(H, j=i+M_{d}\right)}^{\min \left(H=i+N_{d}\right)} x_{i d, j e, k} * c_{i d, j e, q} \\
& +\sum_{d=1}^{D} \sum_{i=0}^{H-1} x_{i d, H d, k} * c_{i d, H d, q}+\left(n_{q k} * N W_{q k}\right)-t_{q k} \geq 0 Q \\
& =1,2, \ldots, Q \text { and } k=1,2 \\
& \sum_{d=1}^{D} \sum_{i=0}^{H-1} \sum_{j=\min \left(H, i+N_{d}\right)}^{\min \left(H, i+M_{d}\right)} x_{i d, j e, k} * c_{i d, j e, q} \\
& +\sum_{d=1}^{D} \sum_{i=0}^{H-1} x_{i d, H d, k} * c_{i d, H d, q}-\left(p_{q k} * N W_{q k}\right)-t_{q k} \geq 0 Q \\
& =1,2, \ldots, Q \text { and } k=1,2 \\
& \operatorname{Min} Z=\sum_{k=1}^{2} \sum_{q=1}^{Q}\left(S F_{q k} * n_{q k}+S F_{q k} * p_{q k}\right)
\end{aligned}
$$

where $x_{i d, j e, k}$ is the number of hectares that entered development type (DT) $d$ in year $i$ and left it in year $j$ when they entered DT $e$, for owner type (OT) $k$ (see Table 5 in the section on normalising ecosystem service goals below); $x_{i d, H d, k}=$ number of hectares that entered DT $d$ in year $i$ stayed in this DT until year $H$, the end of the planning horizon, for OT $k$ (Table 5); and $c_{i d, j e, q}$ is the cumulative value for ecosystem service $q$ over the period from year $i$ to year $j$, in DT $d$. For the harvest revenue ES, the value is expressed as the NPV; $c_{i d, H d, q}$ is the cumulative value for ecosystem service q over the period from year $i$ to year $H$, in DT $d$, for the harvest revenue ES, the value is expressed as the NPV; $D$ is the total number of development types; $M_{d}$ is the maximum number of years a hectare can be assigned to DT $d$; $N_{d}$ is the minimum number of years a hectare can be assigned to DT $d$; and $Q$ is the total number of ecosystem services.

\subsection{Normalising Goals}

The scales that quantify ESs are different and therefore their maximum and minimum ranges vary. Therefore, a normalisation procedure must be implemented so that deviations from each goal are comparable. A method was developed to produce normalising weights for the optimisation (Equations (4)-(6)).

$$
\begin{gathered}
E S \text { scale }_{q k}=\frac{\min \left(\left|q k_{\max }-q k_{\min }\right|\right)}{\left|q k_{\max }-q k_{\min }\right|} \\
N W_{\max }=\frac{1}{\min \left(E S \text { scale }_{q k}\right)} \\
N W_{x k}=N W_{\max } \times E S \text { scale }_{q k}
\end{gathered}
$$

where $q k_{\max } / \min$ is the maximum/minimum biophysical ES supply level for ES $q$ in OT $k$; $\min \left(\left|q k_{\max }-q k_{\min }\right|\right)$ is the ES OT combination with the lowest absolute value of the difference 
between maximum and minimum values; $E S$ scale $_{q k}$ is the scaling factor from 0 to 1 ; $E S$ scale tot min $_{\text {m }}$ is the ES OT combination with the lowest ES normalising value; $N W_{\max }$ is the highest NW to create initial "equal" weightings; and $N W_{q k}$ is the NW for ES $q$ in OT $k$.

\subsection{Owner Types and Attitude Changes}

The area occupied by each OT was spatially delineated based on a polygon's data source (i.e., Forest Service or Coillte). It was assumed that all members in an OT group will respond to policy changes in a similar manner. OT specific attitude differences were incorporated in the model through the scaling of the normalised weights in the goal programming objective function. A description of how the two types of attitude-based scaling factors were determined is presented below, i.e., the "forced" attitude change (point 1) and the attitude change that varies between OTs (point 2):

(1) This uniform change reflects that all OTs will have to modify their attitude equally. Examples are the stringent policy changes associated with the Water Framework Directive and the assumption that NPV is a factor that must be considered by all OTs when making management decisions.

(2) These relative attitude changes apply to timber, hen harrier, deer forage and cover ESs. The change in attitude is not the same for all OTs and is implemented through OT specific scaling factors. These factors are based on the perceived relative change in attitude of each OT. A summary of these scaling factors and scaling is presented in Table 5.

A summary of the scaled and normalised goals is presented in Table 4.

Table 4. A summary of the scaled and normalising goals process.

\begin{tabular}{ccccc}
\hline Ecosystem Service & Owner Type & Scaling Factor & Goal Value & $\begin{array}{c}\text { Normalising Weight } \\
\text { (Weight } \times \text { Scaling Factor *) }\end{array}$ \\
\hline Deer cover & Coillte & 0.00 & $27,629,333$ & 0 \\
Deer cover & Private Forest Owners & 0.50 & $14,150,923$ & 53 \\
Deer forage & Coillte & 0.00 & $23,433,803$ & 0 \\
Deer forage & Private Forest Owners & 0.50 & $11,535,438$ & 62 \\
Hen harrier & Coillte & 0.00 & $34,762,208$ & 0 \\
Hen harrier & Private Forest Owners & 0.50 & $17,770,620$ & 20 \\
Water sedimentation risk & Coillte & 1.00 & 12,143 & 31,622 \\
Water sedimentation risk & Private Forest Owners & 1.00 & 4667 & 112,882 \\
Timber & Coillte & 0.00 & $49,753,761$ & 0 \\
Timber & Private Forest Owners & 0.50 & $30,263,384$ & 9 \\
Recreation & Coillte & 0.00 & $25,277,976$ & 0 \\
Recreation & Private Forest Owners & 0.50 & $13,542,484$ & 24 \\
NPV & Coillte & 1.00 & $480,548,445$ & 1 \\
NPV & Private Forest Owners & 1.00 & $273,188,452$ & 2 \\
\hline
\end{tabular}

* This is the weight required to normalise the ecosystem service goals multiplied by the scaling factor; hence, if the scaling factor is 0 , then the scaled normalising weight will be 0 .

Table 5. Scaling factors (and reason) used to represent the relative attitude change of each owner type.

\begin{tabular}{|c|c|c|}
\hline Owner Type & Scaling Factor & Attitude Change \\
\hline Coillte & $\mathrm{N} / \mathrm{A}$ & $\begin{array}{l}\text { Commercial mandate and fully certified forests mean that the } \\
\text { company has changed and is now obliged to manage their } \\
\text { forests for all purposes of certification. Hence, Coillte will not } \\
\text { change their attitude towards management when new policies } \\
\text { are introduced. }\end{array}$ \\
\hline Private forest owner & 0.50 & $\begin{array}{l}\text { A diverse group of owners with a range of objectives for their } \\
\text { forests. They have committed to having their land in forestry } \\
\text { based on the implemented policies at the time they afforested. } \\
\text { They will to be influenced by newly implemented policies, } \\
\text { however less so than non-forest owning OTs. }\end{array}$ \\
\hline
\end{tabular}


Table 5. Cont.

\begin{tabular}{cl}
\hline \multicolumn{1}{c}{ Owner Type } & \multicolumn{1}{c}{ Scaling Factor } \\
$\begin{array}{c}\text { OTs currently not owning afforested land were investigated } \\
\text { transparency reasons, a description of them is included. }\end{array}$ & $\begin{array}{l}\text { Duesberg et al. [27] found tillage farmers less likely to afforest } \\
\text { than the owners of other, less profitable, types of farming } \\
\text { systems in Ireland. Forestry is a new potential land-use for } \\
\text { them and as a result more farmers in this OT will change } \\
\text { attitudes as a result of policy changes than those in the private } \\
\text { forest OT. }\end{array}$ \\
\hline Ruminant & $\begin{array}{l}\text { This group contains the beef suckling and sheep farming } \\
\text { systems which are often financially comparable with forestry. } \\
\text { It is expected that the next generation, who will inherit the } \\
\text { land in this OT will be more urbanised and open to } \\
\text { afforestation and will be influenced more by future forest } \\
\text { policy changes than the tillage OT. }\end{array}$ \\
\hline
\end{tabular}

\subsubsection{Area Constraints}

Constraints are in place to ensure that the entire area in year 0 is accounted for over the entire planning horizon (Equations (7) and (8)).

$$
\begin{array}{r}
x_{0 d, j e, k}+x_{0 d, H d, k}=A_{d k} k=1,2, \ldots, d \text { and } e=1,2, \ldots, D \text { and } j=i, i+1, \ldots, H-1 \\
x_{i d, j e, k}=\sum_{p=\min \left(H, j+N_{e}\right)}^{\min \left(H, j+M_{e}\right)} x_{j e, p f, k}+x_{j e, H e, k} k=1,2 \text { and } d, e, f=1,2, \ldots, D \text { and } j=1,2, \ldots, H-1
\end{array}
$$

where $x_{0 d, j e, k}$ is the number of hectares assigned to DT $d$ in year 0 , the start of the planning horizon, for OT $k$; $A_{d k}$ is the number of hectares in OT $k$ that are classified as belonging to DT $d$ at the start of the planning horizon. Hectares leaving a DT at year $j$ are not combined with hectares leaving other DTs in the same year, i.e., hectares from different DTs cannot be merged but can only be split. The DT $e$ that a hectare enters has to be compatible with the DT $d$ that it is leaving.

\subsubsection{Policy Related Constraints}

Constraints, not presented in mathematical notation, ensure that ineligible management prescriptions are not prescribed within politically designated zones. It does this by ensuring that the total area of management interventions not permitted on certain areas or the total area of development type regulations is zero in each year of the entire planning horizon. Another constraint (Equation (8)) ensures that all stands that have been clearfelled are reforested. Equation (9) is not applied for uneconomically viable non-reforested areas when replanting duty is lifted for potential future 2 (Table 7).

$$
\sum_{k=1}^{2} \sum_{d=1}^{D} \sum_{i=1}^{H-1} \sum_{j=\min \left(H, i+N_{d}\right)}^{\min \left(H i+M_{d}\right)} x_{i d, j e, k} * r_{i d, k}=0
$$

where $r_{i d, k}$ is a binary variable indicating $\left(r_{i d, k}=1\right)$ the area of development type $d$ in year $i$ for OT $k$ that has not been reforested.

\subsubsection{Industry Regulation}

Evenness constraints (Equation (10)) were implemented to ensure that there is an even supply of timber for each product assortment category over the planning horizon. The evenness constraint was applied separately to the pulp and stake, and to the small and large sawlog timber assortments. 
The constraint ensures that the lowest production level of either assortment in any year of the planning horizon cannot be less than $80 \%$ of the level in the year with the highest assortment production.

$$
\sum_{k=1}^{2} \sum_{d=1}^{D} x_{i d, j e, k} * v_{i d, a}-\left(v_{\max a} * 0.80\right) \geq 0 i=1,2, \ldots, H \text { and } a=1,2
$$

where $v_{i d, a}$ is the timber assortment (i.e., $a=1$ for pulp and stake, $a=2$ for small and large sawlog) volume harvested per hectare of DT $d$ in year $i$; and $v_{\max a}$ is the maximum harvested volume of assortment $a$ in any one year in the planning horizon.

\subsection{Building of Potential Futures}

A qualitative scenario building process was carried out by Bonsu et al. [28]. The stakeholder selection process used purposeful maximum variation sampling as described by Patton [29]. A full description of the method that was used to choose stakeholders for their scenario building process is presented in Bonsu et al. [30]. The scenario building process was facilitated by the findings of Corrigan and Nieuwenhuis [26]. The biophysical ranges from this study were described to the stakeholder group in a workshop setting. This provided the stakeholder group with the biophysical limitations of the CSA, and allowed for a participatory process to take place where the views of the local level stakeholders were consolidated. A group decision making module known as "Parmendies Eidos" [31] was used to produce future scenarios that are plausible in the CSA. These scenarios (for the period 2012-2042) will be referred to in this paper as potential futures (PF). These scenarios are based on factors (known as key factors) which are, according to the stakeholders' expert knowledge, most likely to influence forest management within the CSA in the future. The PFs are in the form of consistent combinations of key factor manifestations. These combinations were perceived as likely to happen simultaneously in the same PF. For example, demand for pulpwood increasing and the establishment of a Combined Heat and Power (CHP) plant in the CSA is considered as consistent; however, the establishment of a $\mathrm{CHP}$ plant was not considered consistent with a decrease in pulpwood demand. A total of five PFs were developed and six key factors were identified: demand for sawnwood, demand for pulpwood, demand for rural development, water protection, forest policies and regulations, and SFM. These qualitative scenarios have been translated into parameters of the GP model formulation. The PFs were modelled using Remsoft Woodstock [32] using an Intel ${ }^{\circledR}$ Core $^{\mathrm{TM}}$ i7-3930K CPU at $3.20 \mathrm{GHz}$ with 32 GB RAM operating Windows 7 Service Pack 1 (64-bit). A BAU PF, as described above, provided a baseline. From this starting point, PFs were developed by changing the relevant baseline parameters and policies in the model. There were four avenues available to implement changes relating to key factor manifestations (Table 6).

Table 6. Summary of methods used to implement policy changes.

\begin{tabular}{cll}
\hline & & Model Change \\
\hline 1 & Alternative management included in the model & Alternative species combination for establishment \\
\hline 2 & Changing how ES values are calculated & $\begin{array}{l}\text { Removing afforestation premiums from the } \\
\text { NPV calculation }\end{array}$ \\
\hline 3 & Changing the spatial arrangements behind the model & Widening buffer zones along watercourses \\
\hline 4 & Inclusion of ESs in objective function & $\begin{array}{l}\text { Water sedimentation risk was included in the objective } \\
\text { function for PFs that include the "more restrictive" } \\
\text { manifestation for water sedimentation risk }\end{array}$ \\
\hline
\end{tabular}

It should be noted that the same methods of quantifying ESs as developed and presented by Corrigan and Nieuwenhuis [26] were implemented in this model. Regardless of whether ESs are included in the objective function, this model will quantify the provision levels of all ESs. The ESs included in the model were: timber production, carbon sequestered in living trees (the difference 
between carbon stock from one year to the next is carbon flow, i.e., the ecosystem service), water sedimentation risk, recreation potential, deer forage, deer cover, habitat for red squirrel, hen harrier and species richness of nesting birds ground vegetation. NPV, although not an ecosystem service per se, is calculated and used in the modelling process as one of the main decision making criteria.

Up to five ESs were brought into the GP optimisation to represent the PFs: NPV, timber production, water sedimentation risk, deer forage and deer cover. ESs were chosen for inclusion in the objective function based on the following criteria:

(1) They represent forest policy-related issues that are currently debated in the local context and will continue to be issues in the future.

(2) Owner Type demands are diverse and, in some PFs, owners will aim to provide different ESs.

The translation of scenarios into the GP model involved the change of management planning options as listed in methods 1 to 3 (Table 6) and of management policy parameters (Table 7). It involved further the compilation of ES to consider in the GP objective function in each PF (Table 8).

Table 7. A summary of management policy model changes, by key factors, for each potential future.

\begin{tabular}{ccccccc}
\hline $\begin{array}{c}\text { Potential } \\
\text { Future }\end{array}$ & $\begin{array}{c}\text { Demand for } \\
\text { Sawnwood }\end{array}$ & $\begin{array}{c}\text { Demand for } \\
\text { Pulpwood }\end{array}$ & $\begin{array}{c}\text { Demand for Rural } \\
\text { Development }\end{array}$ & $\begin{array}{c}\text { Water } \\
\text { Protection }\end{array}$ & $\begin{array}{c}\text { Replanting } \\
\text { Requirement }\end{array}$ & SFM \\
\hline BAU & Same & Same & No CHP plant & Same & Same \\
\hline 2 & Same & Same & No CHP plant & Same & Lifted \\
\hline 3 & $\begin{array}{c}10 \% \text { increase } \\
\text { in price }\end{array}$ & $\begin{array}{c}10 \% \text { increase } \\
\text { in price }\end{array}$ & CHP plant built & Same & Same \\
\hline 4 & $\begin{array}{c}10 \% \text { increase } \\
\text { in price }\end{array}$ & $\begin{array}{c}10 \% \text { increase } \\
\text { in price }\end{array}$ & CHP plant built & Water & Same & SFM \\
measures & & Same \\
\hline 5 & Same & Same & No CHP plant & Water & measures & Same \\
\hline
\end{tabular}

${ }^{1} \mathrm{CHP}=$ combined heat and power plant; ${ }^{2}$ Water measures = Water buffer zones doubled: $6 \mathrm{~km}$ FPM 25 to $50 \mathrm{~m}$; FPM 10 to $20 \mathrm{~m}$. Increased emphasis on water sedimentation risk ES; ${ }^{3} \mathrm{SFM}$ measures $=$ Bog restoration an option. Increased emphasis on ecological ESs.

Table 8. Ecosystem service included in the objective function for each potential future.

\begin{tabular}{cccccc}
\hline Potential Future & Deer Cover & Deer Forage & Timber & NPV & Water \\
\hline BAU & & & & $\mathrm{X}$ & \\
2 & & & & $\mathrm{X}$ & \\
3 & & $\mathrm{X}$ & $\mathrm{X}$ & $\mathrm{X}$ & \\
4 & $\mathrm{X}$ & $\mathrm{X}$ & & $\mathrm{X}$ & $\mathrm{X}$ \\
5 & $\mathrm{X}$ & & & $\mathrm{X}$ \\
\hline
\end{tabular}

\section{Results}

The model outputs contain information on management approaches selected by each owner type (OT). However, as these choices depend to a large extent on the forest composition for each OT, which is quite different at the start of the planning horizon, presenting the results by OT is not very useful within the context of this paper. For this reason, the results section will focus on landscape level trends. The forest age and yield class composition for the BAU PF will be presented first. This initial BAU description will be followed by a comparison of the relative change in selected management approaches and ES provision levels between PFs.

\subsection{BAU Potential Future}

The age class distributions (Figure 2) show a dip in the 1-10 year age class at the start of the planning horizon (point 1 ) and this progresses to the 21-30 age class by approximately year 26 (points 1 , 2 and 3 in Figure 2). The most recent GIS forest dataset that was available in 2012 for private forests 
was published in 2007. Since 2007, more non-forested land has been afforested but no update for private forests exists since the 2007 dataset. As a result, there are no privately owned forests that are six years old or less at the beginning of the planning horizon (i.e., the youngest privately owned forests are between six and 10 years old). This accounts for the initial decline in the 1-10 year age class over the first five years of the planning horizon, as the private forests in this age class are all between six and 10 years of age at the start of the planning horizon and moves into the 11-20 year age class by Year 5 of the planning horizon. This dip dissipates between the Years 31 and 36, which corresponds with the average clearfell age of for conifers of 41 years. The age class distribution becomes more smooth at this stage as a proportion of the 31-40 year age class is retained (under the CCF management approach and buffer zones which have been established within the first 10 years of the planning horizon) and will continue to mature, while the areas in this age class that were clearfelled are reforested. This results in the development of a less pronounced dip in the second half of the planning horizon, identified for the 1-10 year age class by Year 48 (point 4 in Figure 2), and continuing to Year 57 (point 6 in Figure 2).

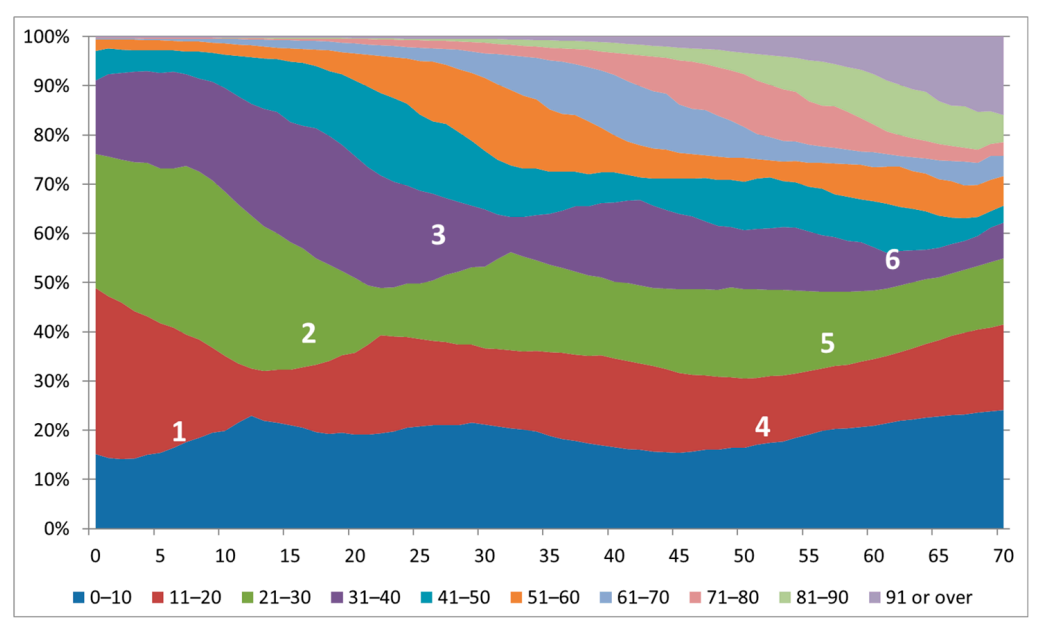

Figure 2. Structure of the forests, in 10-year age classes, for the Business As Usual Potential Future for each year of the planning horizon.

\subsubsection{Yield Class Assessment}

Initially, $81 \%$ of the CSA's forests are productive, i.e., have a yield class equivalent of 14 or higher. For the current rotation, many forests have been established with lodgepole pine (a species suited to marginal sites) with the help of multiple applications of artificial fertiliser. This ensures successful establishment and results in productive forest. Current Irish policy means however that fertilisation is only a once-off option at establishment (on peat sites) to ensure successful re-establishment and this one application does not increase yield class to the same extent, hence the proportion of productive forest decreases to circa $40 \%$ over time.

\subsubsection{Proportion of the Case Study Area under Each Management Approach}

It is assumed that the forest management begins with a traditional rotation based approach. The optimisation selects alternative options for all PFs. This means that the rate of change from traditional forest management can be assessed and compared over the course of the planning horizon (Figure 3).

A relatively large proportion of CCF is established in all PFs (23\% of the CSA by year 35 in the BAU PF). One benefit of CCF is that timber can be harvested for the remainder of the planning horizon without the cost of re-establishment (i.e., natural regeneration is assumed). However, the CCF management approach can be selected or sometimes "forced" to happen for a variety of reasons. For instance, CCF stands include all Coillte owned broadleaf forests and many Natura 2000 areas. 
The BAU PF and PF 3 are more focused on timber production than the other PFs and as a result, less CCF management is introduced in these PFs compared to PFs 4 or 5. PF 2 has less CCF management as some of the areas that would typically enter CCF are now clearfelled and not reforested (using the non-reforested management approach). The proportion of buffer zone area in the BAU PF in year 35 is $1.8 \%$, while the wider buffer zones and the reduced economic focus in PFs 4 and 5 mean that a higher proportion of the CSA is managed as buffer zone in these scenarios, i.e., $4.19 \%$ and $5.29 \%$ for PFs 4 and 5 in year 35. PF 2 results in the smallest area of buffer zones; this is due to non-reforestation being an option in this PF. When changing management approach from traditional forest management to CCF or buffer zone, revenue can be generated from timber harvesting without the cost of restocking the area (fully) with trees. The establishment of NWS is not beneficial financially and takes a long time (60 years post establishment) to provide higher habitat ratings, and therefore has little uptake in the PFs.

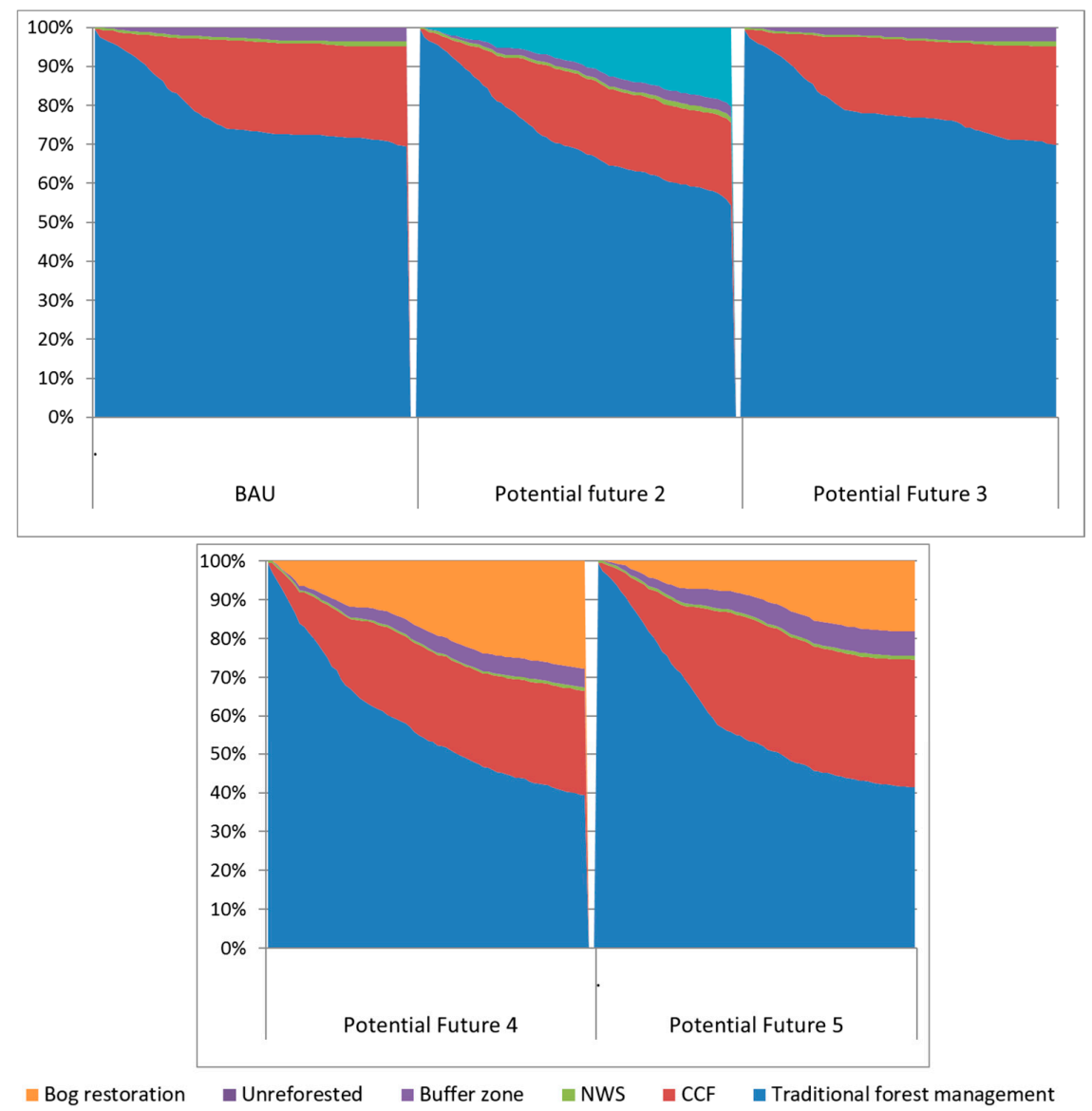

Figure 3. Management approaches as a proportion of the CSA for each Potential Future over the 70-year planning horizon.

The management approaches which are only available when certain key factors are chosen in the model are chosen by the optimisation to reach the ES goals specified in the model. For instance, in PF 2 the key factor change is to allow strategic non-reforestation and circa $20 \%$ of the CSA forest is not reforested post-clearfell. It is assumed that a site will be restocked if it is financially viable to do so, however all OTs in PF 2 have the choice not to restock forests if they are unproductive. As there is a much higher proportion of unproductive forest in Coillte owned land, a much higher proportion of Coillte land is non-reforested (13.33\% by year 35$)$ than private forest land ( $0.49 \%$ by year 35$)$. In PFs 4 and 5, which are the only PFs where bog restoration is an option, respectively $28 \%$ and $18 \%$ of the Coillte owned and privately owned CSA forests are restored to bog by the end of the planning horizon. 


\subsubsection{ES Provisions}

Over the first one third of the planning horizon for all PFs, many of the mature forests are harvested after which there is a decline in timber production (within the bounds of the volume smoothening constraints), followed by an increase in harvest in the final third of the planning horizon when these harvested and reforested areas mature again. This maturing age class structure in the final two thirds of the planning horizon increases the provision of most biodiversity ESs for the BAU PF (Figure 4), with the exception of hen harrier habitat which is provided by young forest. The increase in harvesting of these mature forests in the final third of the planning horizon means that hen harrier scores increase (as they are attracted to young or open land-use types), while recreation scores decline as high recreational potential is strongly associated with mature forest. Less change is observed for other ESs, as young forest, although not as suited as mature forest to provide these ESs, does provide relatively high levels of ESs, e.g., deer forage and nesting birds.
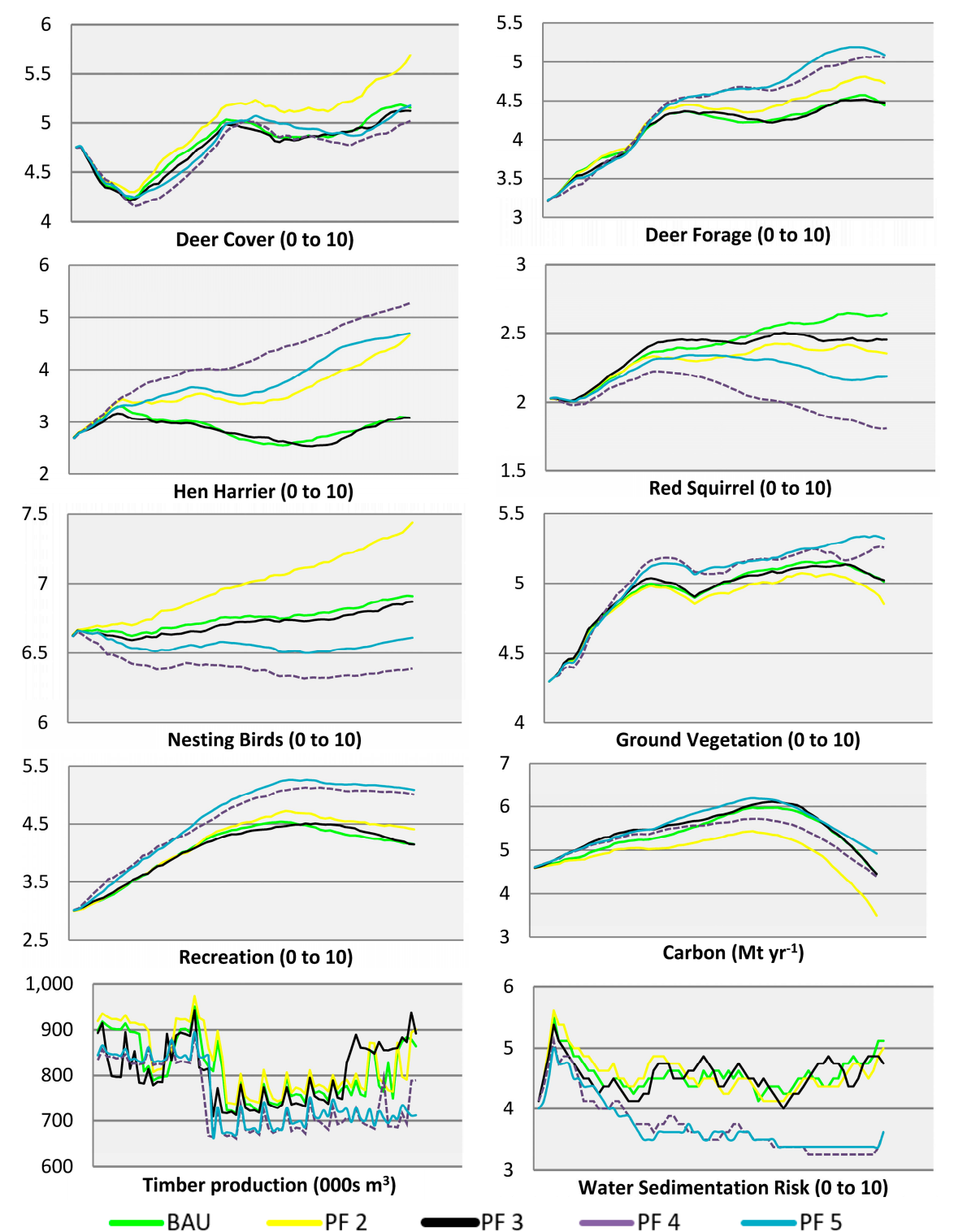

Figure 4. ES provisions for all Potential Futures (PF) over a 70-year planning horizon ( $x$-axis). The $y$-axis values are specific to each ecosystem service provision level achieved, while the maximum and minimum values of each ES scale are specified on each graph (except for timber and carbon). 
A majority (38 out of 50) of the 10 ES provision levels in all five PFs had increased by the end of the planning horizon compared to their values at the beginning of the planning horizon (and the water sedimentation risk had decreased in most PFs). This gives an indication that the dominant management approach at the start of the planning horizon, traditional forest management (the proportion of which declines in all PFs), is focused on maximising only NPV over time. The CSA's composition changes to a more multifunctional environment through the use of other management approaches in all PFs and hence a more diverse mix of ESs is provided.

PF 4 has the lowest average ES provision level for red squirrel. The larger amount of bog restoration, replacing mature forest in this PF, reduces the provision of this ES considerably compared to the levels in all other PFs. Similarly, habitat provision levels for nesting birds are low for the bog land-use and, as a result, nesting bird habitat declines in PFs 4 and 5.

For PFs in which water protection measures (i.e., wider buffer zones) are implemented (i.e., 4 and 5), the water sedimentation risk is significantly lower over the course of the planning horizon, even accounting for the initial clearfelling disturbance. The BAU and PFs 2 and 3, which do not include wider buffer zones, result in much higher water sedimentation risk.

\section{Discussion}

The concept of landscape and ES management are very new in Ireland and this study builds on the work of Corrigan and Nieuwenhuis [26] and further exposes forest managers and stakeholders to these concepts. The model described in this study is a first attempt to use GP to model forest related land-use change in Ireland. An important innovation compared to the former Corrigan and Nieuwenhuis study lies in the modelling of forest related policy and industry changes. These make the model outputs more realistic, which means that the model is much more useful for explaining the concept of ES synergies and trade-offs to local level stakeholders. During the interactions with the stakeholders, the potential benefits of further model development and refinement were identified, especially in relation to spatial and climate change aspects.

The ES provisions resulting from the PFs indicate that a more desirable mix of ESs can be achieved in the future than the ES provision levels in 2012. However, studies often indicate that some ES synergies and trade-offs will happen when evaluating the enhanced provisions of others [33]. The results of this study were used in a study by Biber et al. [34] who summarised and compared the ES synergies and trade-offs in 20 CSAs across Europe [16]. That study confirmed that typically biodiversity increased when management was less intensive. The WP CSA described in full in this paper produced slightly different results compared to this general European trend, because while the less intensive management approaches (i.e., bog restoration and non-reforested land) provide high levels of some ESs (i.e., deer cover, hen harrier and nesting birds), they also result in low provision levels of some biodiversity ESs (i.e., red squirrel and ground vegetation). There is a large uptake of these non-forest management approaches when they are available in a PF. This indicates that more diverse and/or less forest than the current composition and extent would result in ES provision levels closer to the desired levels, especially given the relatively unproductive forests in this CSA. Even though the stakeholders that were interviewed did not express strong views against forestry per se [28], the model identified greater benefits from non-forest land-uses on less productive areas, i.e., bog restoration and strategic non-reforestation. The reason for the choice of non-forest management approaches, when available in a PF, is that the model is basing solutions on multiple objectives, some of which have considerably higher scores for non-forest land-uses, outweighing the loss of NPV. For instance, when maximising NPV, recreation provision declines towards the end of the planning horizon (PFs BAU, 2 and 3), meaning that while providing for one objective (NPV) at the highest level, other objectives are negatively affected. When the objective function incorporates two or more ESs that require different types of land-use for their provision, this study indicates that more desired levels of a wider mix of ESs can be provided while only marginally reducing the provision of one ES (in this example, NPV), similar to the findings of other studies [10]. 
The GP model can accommodate multiple objectives as goals which the GP optimisation aims to achieve simultaneously. The biophysically optimal results from Corrigan and Nieuwenhuis [26] were obtained for one ES at a time without taking into account current policy and industry demands. These were included as hard constraints rather than goals to avoid interfering with the normalised ESs specified as goals (which rely on a balance of calculated weights for their normalisation). None of the goals were reached for any PF. An alternative would be to have the goal levels set at achievable levels by local stakeholders. However, in the case where all goals were achieved, the model's solution could be considered sub-optimal as the landscape has the potential to produce the ESs at higher levels. With this in mind, consulting with an expert panel, as investigated by Hotvedt [35] for sawmill timber supply, could be useful to ensure goals are set at levels appropriate for the goal programming approach. In addition, many of the quantification methods for the wide range of ESs in this study are new and hence stakeholders were less familiar with these methods than the timber experts in the Hotvedt study who were only asked to assign goals for timber supply. With this in mind, the Pareto efficiency method might be useful for comparing relative ES provision levels [36,37]. A transparent method such as this would allow stakeholders to identify the impact of changing the level of one ES provision target on others, with a view towards reaching a consensus on suitable goals. This would be particularly useful when the process involves multidisciplinary, local stakeholder groups.

Caveats

(1) Some policy decisions are made on a case by case basis. Even if areas share the same characteristics, it is possible for multiple politically enforced management decisions to be made. For example, in Special Areas of Conservation (SACs), reforestation with broadleaves is the typical policy to choose (and the one specified in the model), however in some very special circumstances, conifers may be planted in small areas in SACs for reasons that could not be quantified and included in the model.

(2) The model described in this study only accommodates spatially related characteristics before the optimisation. This reduces the practical applicability of the resulting PFs. For example it is not possible for the model to determine a suitable habitat for the red squirrel, i.e., a homogenous area of at least 200 to 300 ha of suitable forest is required [38]. Remsoft's heuristic spatial planning software called "Stanley" [39,40] could be used to deal with some of the spatial aspects.

(3) The method of determining scaling factors for owner types was largely based on qualitative scientific research and the research team's expertise. Although intention to afforest has been linked to farm and social characteristics [27], further research is necessary in Ireland to identify how these characteristics influence forest management and even land-use management in general. The agent-based model developed by Daigneault and Fraser [41] for New Zealand could be a useful approach. Their model, which is focused on agriculture, links various human life stages with the propensity to proceed with certain management intentions.

\section{Conclusions}

In all PFs, management approaches changed away from the traditional forest management approach that currently dominates in the Western Peatlands. The change of management approach brings with it a change in ES provisions, resulting in a more diverse and also more desirable mixture according to the preferences outlined by the local level stakeholder group. Current forest policy means that many of the financially unproductive forests that are clearfelled must be reforested. The PFs indicate that some deforestation can be beneficial in achieving the stakeholders' desired mix of ESs.

When the findings of this modelling project were described to academic and national level stakeholders, all parties appreciated the quantitative approach, even though the approach only included spatial constraints before the optimisation algorithm was ran. They felt that being able to assess the relative changes in ES provision levels and management approaches in a range of PFs was a useful prompt for discussion, especially for a multidisciplinary stakeholder group with little 
shared familiarity with such a broad range of ESs. All parties also felt that the approach was useful to investigate policy and industry changes and they appreciated the model's potential to produce estimates of changing ES provision levels and management approaches over time and not just at the start and end of the planning horizon. Coillte, who also use Remsoft, are interested in incorporating several ESs into its management planning procedures.

Acknowledgments: This project has received funding from the European Union's Seventh Program for research, technological development and demonstration under grant agreement No. 282887 (INTEGRAL).

Author Contributions: Edwin Corrigan and Maarten Nieuwenhuis designed the study and interpreted the consolidated results. Edwin Corrigan wrote the paper. Maarten Nieuwenhuis contributed to writing the paper. Both authors contributed substantial data, meta-information, and result interpretation.

Conflicts of Interest: The authors declare no conflict of interest.

\section{Abbreviations}

The following abbreviations are used in this manuscript:

$\begin{array}{ll}\text { BAU } & \text { Business As Usual } \\ \text { CCF } & \text { Continuous Cover Forestry } \\ \text { CHP } & \text { Combined Heat and Power } \\ \text { CSA } & \text { Case Study Area } \\ \text { ES } & \text { Ecosystem Service } \\ \text { FPM } & \text { Freshwater Pearl Mussel } \\ \text { GP } & \text { Goal Programming } \\ \text { NPV } & \text { Net Present Value } \\ \text { NWS } & \text { Native Woodland Site } \\ \text { OT } & \text { Owner Type } \\ \text { PF } & \text { Potential Future } \\ \text { SFM } & \text { Sustainable Forest Management } \\ \text { WP } & \text { Western Peatlands }\end{array}$

\section{References}

1. Barrett, F.; Somers, M.J.; Nieuwenhuis, M. PractiSFM-An Operational Multi-Resource Inventory Protocol for Sustainable Forest Management; CABI: Wallingford, UK, 2007; pp. 224-237.

2. Nieuwenhuis, M.; Tiernan, D. The Impact of the Introduction of Sustainable Forest Management Objectives on the Optimisation of PC-based Forest-level Harvest Schedules. For. Policy Econ. 2005, 7, 689-701. [CrossRef]

3. Turner, B.J.; Chikumbo, O.; Davey, S.M. Optimisation Modelling of Sustainable Forest Management at the Regional Level: An Australian Example. Ecol. Model. 2002, 153, 157-179. [CrossRef]

4. Food and Agriculture Organization (FAO). Development of the National-Level Criteria and Indicators for the Sustainable Management of Dry Forest of Asia: Workshop Report; Asia-Pacific Forestry Commission: Bangkok, Thailand, 2000.

5. Alcamo, J.; Bennett, E.M. Ecosystems and Human Well-Being: A Framework for Assessment; Island Press: Washington, DC, USA, 2003.

6. Gómez-Baggethun, E.; de Groot, R.; Lomas, P.L.; Montes, C. The History of Ecosystem Services in Economic Theory and Practice: From Early Notions to Markets and Payment Schemes. Ecol. Econ. 2010, 69, 1209-1218. [CrossRef]

7. King, R.T. Wildlife and management. N. Y. Stake Conserv. 1966, 20, 8-11.

8. Westman, W.E. How Much Are Nature's Services Worth? Science 1977, 197, 960-964. [CrossRef] [PubMed]

9. Millennium Ecosystem Assessment (MEA). Available online: http://www.unep.org/maweb/en/index.aspx (accessed on 5 October 2013).

10. De Groot, R.S.; Alkemade, R.; Braat, L.; Hein, L.; Willemen, L. Challenges in Integrating the Concept of Ecosystem Services and Values in Landscape Planning, Management and Decision Making. Ecol. Complex. 2010, 7, 260-272. [CrossRef]

11. Fléchard, M.-C.; Carroll, M.S.; Cohn, P.J.; Ní Dhubháin, Á. The Changing Relationships between Forestry and the Local Community in Rural Northwestern Ireland. Can. J. For. Res. 2007, 37, 1999-2009. [CrossRef] 
12. Tiernan, D. Redesigning Afforested Western Peatlands in Ireland. In After Wise Use-The Future of Peatlands, Proceedings of the 13th International Peat Congress: Peatland Forestry, Tullamore, Ireland, 8-13 June 2008; Irish Peatland Society: County Kildare, Ireland, 2008.

13. Cregan, M.; Murphy, W. A Review of Forest Recreation Research Needs in Ireland; COFORD: Dublin, Ireland, 2006.

14. Ní Dhubháin, Á.; Fléchard, M.-C.; Moloney, R.; O’Connor, D. Stakeholders' Perceptions of Forestry in Rural Areas-Two Case Studies in Ireland. Land Use Policy 2009, 26, 695-703. [CrossRef]

15. Nieuwenhuis, M.; Williamson, G.P. Harvesting Coillte's Forests: The Right Tree at the Right Time. Ir. For. 1993, 50, 122-133.

16. INTWEGRAL. Available online: http:/ /www.integral-project.eu/ (accessed on 21 August 2016).

17. Diaz-Balteiro, L.; González-Pachón, J.; Romero, C. Goal Programming in Forest Management: Customising Models for the Decision-maker's Preferences. Scand. J. For. Res. 2012, 28, 166-173. [CrossRef]

18. Aldea, J.; Martínez-Peña, F.; Romero, C.; Diaz-Balteiro, L. Participatory Goal Programming in Forest Management: An Application Integrating Several Ecosystem Services. Forests 2014, 5, 3352-3371. [CrossRef]

19. McDonagh, M. (Resource Optimisation Team Leader, Coillte, Oran Town Centre, Oranmore, Galway, Ireland); Corrigan, E. (UCD Forestry, School of Agriculture \& Food Science, Dublin, Ireland). Coillte Forest Personal communcation, 2012.

20. Renou, F.; Farrell, E.P. Reclaiming Peatlands for Forestry: The Irish Experience. In Restoration of Boreal and Temperate Forests; CRC Press: Boca Raton, FL, USA, 2005.

21. Forest Service. Irish National Forest Standard; Magner Communications: Dublin, Ireland, 2000.

22. Johnson, K.N.; Scheurman, H.L. Techniques for Prescribing Optimal Timber Harvest and Investment Under Different Objectives-Discussion and Synthesis. For. Sci. 1977, 23, a0001-z0001.

23. Forest Service. Code of Best Forest Practice—Ireland; Department of the Marine and Natural Resources: Dublin, Ireland, 2000.

24. Forest Service. Native Woodland Scheme-Establishment; Department of Agriculture Fisheries and Food: Wexford, Ireland, 2011.

25. Forest Service. Forest Service Appropriate Assessment Procedure-Appendix B Appropriate Assessment Procedure (AAP) Requirements Regarding Hen Harrier SPAs and Afforestation; Forest Service: Wexford, Ireland, 2012.

26. Corrigan, E.; Nieuwenhuis, M. A Linear Programming Model to Biophysically Assess Some Ecosystem Service Synergies and Trade-Offs in Two Irish Landscapes. Forests 2016, 7, 128. [CrossRef]

27. Duesberg, S.; O'Connor, D.; Ní Dhubháin, Á.; Upton, V. Factors Influencing Irish Farmers' Afforestation Intentions. For. Policy Econ. 2014, 39, 13-20. [CrossRef]

28. Bonsu, N.O.; Dhubháin, Á.N.; O'Connor, D. Evaluating the use of an Integrated Forest Land-Use Planning Approach in addressing Forestry Conflicting Demands: Experience within an Irish Forest Landscape. Futures 2016, in press. [CrossRef]

29. Patton, M.Q. Qualitative Research E Evaluation Methods; SAGE Publications: Thousand Oaks, CA, USA, 1990.

30. Bonsu, N.O.; Dhubháin, Á.N.; O'Connor, D. Understanding forest resource conflicts in Ireland: A case study approach. Land Use Policy 2015, in press. [CrossRef]

31. Parmenides. Parmenides Eidos-Visual Reasoning. Available online: https://www.parmenides-eidos.com/ eidos9/us/ (accessed on 21 August 2016).

32. Walters, K.R. Design and Development of a Generalised Forest Management System: Woodstock. In Proceedings of the International Symposium on Systems Analysis and Management Decisions in Forestry, Valdivia, Chile, 9-12 march 1993; Remsoft Inc.: Valdivia, Chile, 1993.

33. Pereira, S.; Prieto, A.; Calama, R.; Diaz-Balteiro, L. Optimal Management in Pinus pinea L. Stands Combining Silvicultural Schedules for Timber and Cone Production. Silva Fenn. 2015, 49, 1226. [CrossRef]

34. Biber, P.; Borges, J.G.; Moshammer, R.; Barreiro, S.; Botequim, B.; Brodrechtová, Y.; Brukas, V.; Chirici, G.; Cordero-Debets, R.; Corrigan, E.; et al. How Sensitive Are Ecosystem Services in European Forest Landscapes to Silvicultural Treatment? Forests 2015, 6, 1666-1695. [CrossRef]

35. Hotvedt, J.E. Application of Linear Goal Programming to Forest Harvest Scheduling. South. J. Agric. Econ. 1983, 15, 103-108. [CrossRef]

36. Borges, J.G.; Garcia-Gonzalo, J.; Bushenkov, V.; McDill, M.E.; Marques, S.; Oliveira, M.M. Addressing Multicriteria Forest Management with Pareto Frontier Methods: An Application in Portugal. For. Sci. 2014, 60, 63-72. [CrossRef] 
37. Borges, J.G.; Marques, S.; Garcia-Gonzalo, J.; Rahman, A.U.; Bushenkov, V.; Sottomayor, M.; Carvalho, P.O.; Nordström, E.-M. A Multiple Criteria Approach for Negotiating Ecosystem Services Supply Targets and Forest Owners' Programs. For. Sci. 2016. [CrossRef]

38. Pepper, H.; Patterson, G. Red Squirrel Conservation; Forestry Commission: Edinburgh, UK, 1998.

39. Walters, K.R.; Feunekes, U.; Cogswell, A.; Cox, E. A Forest Planning System for Solving Spatial Harvest Scheduling Problems; Remsoft Inc.: Fredericton, NB, Canada, 1999.

40. Könny, N.; Tóth, S.F.; McDill, M.E.; Rajasekaran, B. Temporal Connectivity of Mature Patches in Forest Planning Models. For. Sci. 2014, 60, 1089-1099.

41. Daigneault, A.J.; Fraser, M. Estimating Impacts of Climate Change Policy on Land-use: An Agent Based Modeling Approach. In Proceedings of the Agricultural \& Applied Economics Association's 2012 Annual Meeting, Seattle, WA, USA, 12-14 August 2012.

(C) 2016 by the authors; licensee MDPI, Basel, Switzerland. This article is an open access article distributed under the terms and conditions of the Creative Commons Attribution (CC-BY) license (http://creativecommons.org/licenses/by/4.0/). 